(C) 1999 The Chemical Society of Japan

- 一 般論文一

\title{
キトサン誘導体の合成とその硝酸イオンの吸着特性 ${ }^{12)}$
}

(1999 年 2 月 1 日受理)

馬場由成*·大熊康之十·河野恵宣

\begin{abstract}
本研究では硝酸性窒素除去のための新規吸着凧の開発を目的として，かにやえびの殼から得られるキ トサンを素材とした数種のキトサン誘導体を新規に合成し, その硝酸性窒素の除去特性について検討し た. キトサン誘導体として，キトサン由来のアミノ基を利用し，第一級アミン，第二級アミン，第四級 アンモニウムイオンを官能基とするもの，さらに硝酸イオンの鋳型構造を有する第四級アンモニウムイ オンを官能基とするもの, の 4 種類のキトサン誘導体を用いた. 吸着実験はすべてバッチ法により行 い, 単一溶液および塩化物イオン, 硫酸イオン共存下の混合溶液からの吸着実験を行った. その結果, 単一溶液からの吸着では第一級，第二級アミンを有するキトサンおよびキトサン誘導体による硝酸性窒 素の吸着は， $\mathrm{pH}$ に大きく依存し， $\mathrm{pH}<2$ および $\mathrm{pH}>6$ の領域では吸着量が激減することが明らかと なった，一方，第四級化キトサンおよび硝酸イオンの鋳型構造を有する第四級化キトサンでは，中性付 近でも高い吸着量を示した. 特に, 中性付近では硝酸イオンの鋳型効果が発現し, 鋳型を有していない 第四級化キトサンの場合と比較すると， 2 倍程度の吸着量を示した. しかしながら, 混合溶液からの吸 着では硝酸イオンの鋳型効果は発現せず，中性付近での選択性については第二級アミンを有するキトサ ン誘導体が最も高い選択性を示した。
\end{abstract}

\section{1 緒 言}

近年, 有機塩素化合物を代表とする各種化学物質による地下水 污染や土壤污染が深刻な状況にあり，特に最近では飲料用の地下 水に関して硝酸性空素による污染が重要な問題となってきてい

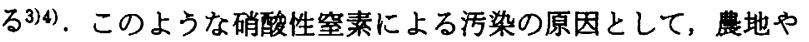
コルフ場などに散布された絰素肥料や家畜の排泄物に含まれる窒 素成分が土壤中で生物学的硝化反応を受け硝酸性窒素となり, 地 下水に漫透していく場合, あるいは酸性雨の影響により土喠に保 持されていた窒素成分が溶出し，地下水に浸透していく場合，さ らには下水中の窒素成分が地下漫透する場合など, さまざまな原 因が挙げられている.なかです，我が国においては大量施肥によ る窒素肥料の影響が最も大きいといわれている. 地下水の硝酸性 窒素污染は，土地の利用形態や飲料水に対する地下水依存の割合 の大きさなどから欧米でより深刻な事態となっているが，我が国 においてむ水道水質基準を超える湦度の硝酸性窒素が検出される 井戸が多くなっていることが報告されている5). 最近では，この ように飲料水中に硝酸性窒素が大量に含まれることによる健康障 害が指摘され，メトへモグロビン血症と発がん性の二つが举げら れており，早急な対策が望まれている。

最近，かにやえびの殼から得られるキチン・キトサンの有効利 用に関する研究が活発に行われているが6)，その有効利用技術の 開発は発展途上の段階であり, 現在そのほとんとが生コミとして

\footnotetext{
宮崎大学工学部, 889-2192 宮崎市学園木花台西 1-1

†チッソ株式会社, 867-0053 水俣市野口町 867
}

廃棄されている状況である. キチン・キトサンは生体起源の素材 であり，今後その有効利用技術に関する研究開発が非常に重要で あると考えられる．特に，キトサンは反応活性な第一級アミノ基 を有するため化学修飾が容易であり，さまさまな機能を付与でき ることが期待される，今までに，貴金属や㻴境污染重金属の吸着 剤としての利用に関する研究は数多くなされているが7)-11)，有 機有害物質や硝酸イオンなどの陰イオンの吸着剤としての応用に 関する研究はほとんど見当たらない.すでに，大賀ら ${ }^{11}$ は金属 イオンの鋳型構造をキトサンに付与し, 鋳型に用いた金属イオン に選択性の向上が発現することを明らかにしている，そこで著者 らは金属イオンのようなカチオンだけでなく，硝酸イオンなどの ような陰イオンに対してもその鋳型構造が付与できることを期待 し, 本研究を企画した. このような観点から，本研究ではバイオ マス資源の有効利用のための新しい技術開発の一環として，キト サンを利用した硝酸イオンの新しい吸着放を創製することを目的 とし，数種のキトサン誘導体を新しく合成し，その硝酸イオンの 吸着特性をキトサン誘導体の化学構造と関連つけ, 検討した.

\section{2 実験}

\section{1 試莱および試料}

キトサンはカト吉(侏から提供された脱アセチル化度 $100 \%$ ，分 子量 80000-100000の粉末状のものを使用した．その他の試薬 は和光純薬(侏製の特級試薬をそのまを使用した.

\section{2 キトサン誘䁚体の調整 ${ }^{12)}$ とその化学楧造}

キトサンはそのままでは水には溶解しないが，有機酸や希薄な 
無機酸には溶解することが知られている6)。したがって，キトサ ン誘導体も酸に溶解すると予想されるので，キトサン誘導体を再 利用するためには再生剤と考えられる酸やアルカリに対して安定 なキトサン樹脂を得なければならない，そのためにはキトサン誘 導体を架橋すればよいが，一方ではキトサンのアミノ基に架橋反 応が優先的に起こり，硝酸性窒素を捕捉する部位をつふしてしま うことになる，そこで，この相反する矛盾を解決するために前 報9)で報告したような方法により，キトサンあるいはキトサン誘 導体を架橋することを提案する，著者らは第一級アミンを有する 架橋キトサン，あるいは第二級アミンを有する架橋キトサンを得 るために，キトサンの第一級アミンとアルデヒド誘導体との反応 によりSchiff 塩基を形成させ，アミノ基を保護した，その後 1,2-エポキシ-3-クロロプロパン(エピクロロヒドリン)により架 橋し, Schiff 塩基を塩酸により分解あるいは水素化ホウ素ナトリ ウムによって還元することにより，それぞれのキトサン誘導体を 容易に得ることができると考えた．この方法を利用して，ここで 用いた架橋キトサン樹脂を合成した．以下にその合成法を示す.

2.2.1 第一級アミンを有する架橋キトサン(CLC)の合成：キ トサン $16 \mathrm{~g}$ (グルコサミン単位 $0.1 \mathrm{~mol}$ )を $2 \mathrm{wt} \%$ の酢酸水溶液 $400 \mathrm{~mL}$ に溶解し，メタノール $200 \mathrm{~mL}$ で希釈した．その溶液に $1 \mathrm{~mol}$ のホルムアルデヒドの水溶液を烓素雾囲気下でゆっくりと 滴下し，Schiff 塩基を形成させ，一晚放㯰した。，その後，ゲル化 したキトサンSchiff 塩基をエタノール中に浸し，十分洗浄した. このゲルを架橋するために洗浄したキトサンSchiff 塩基を DMSO 中で膨潤させ， $1 \mathrm{~mol}$ のエピクロロヒドリンを十分含漫 させ, $0.5 \mathrm{~mol} \mathrm{dm}{ }^{-3}$ の水酸化ナトリウム $400 \mathrm{~mL}$ を加え, $60{ }^{\circ} \mathrm{C}$ で 24 時間摫汼し，架橋を行った。その後, $1 \mathrm{~mol} \mathrm{dm}^{-3}$ の塩酸 に漫し，24 時間㭡拌してSchiff塩基を分解した。汇別後，1 $\mathrm{mol} \mathrm{dm}{ }^{-3}$ 水酸化ナトリウム溶液に浸漬してから中性になるまで 水洗し, 真空乾燥したものを試料とした.

2.2 .2 第二級アミンを有する架橋キトサン(GCLC)の合成 : 2.2.19場合と同様に行い，キトサン $16 \mathrm{~g}$ を溶解させた酢酸一メ タノール溶液に, $0.5 \mathrm{~mol}$ のグルタルアルデヒドを窒素雾囲気下 でゆっくりと滴下し, Schiff 塩基を形成した. 一晚放置した後, $1 \mathrm{~mol}$ の水素化ホウ素ナトリウムを用いて Schiff 塩基を第二級ア
ミンに還元した，後処理は2.2.1 と同様である.

2.2 .3 第四級化架棉キトサン (TMC)の合成 : キトサン $\left(\mathrm{C}_{6} \mathrm{H}_{11}\right.$ $\left.\mathrm{NO}_{4}\right)_{n} 16 \mathrm{~g}(0.1 n \mathrm{~mol})$ を水一エタノール $(2: 1)$ 混合溶媒 $600 \mathrm{~mL}$ に分散させ， $70^{\circ} \mathrm{C} に$ 保ち $0.7 \mathrm{~mol}$ のヨウ化メチルを滴下した. 8

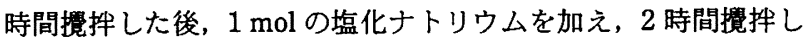
て安定な $\mathrm{Cl}$ 型にした．その後，アセトン中に一尽夜漫漬し，ゲ ル化させた．架橋は2.2.1と同様にして行った．架橋後，沪液に 塩化物イオンが検出されなくなるまで水洗した，そのことは，沪 液に硝酸銀水溶液を数敵加え塩化銀の沈殷が生じるかどうかで判 断した．沪別後，中性になるまで水洗し，真空乾燥したものを試 料とした。

2.2.4 硝酸イオン鋳型架橋第四級化キトサン(NTMC)の合 成 : 2.2.3 と同様な方法で第四級化した後, 10 倍モル量の硝酸ナ

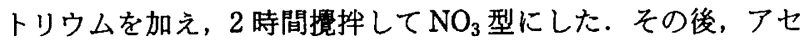
トン中に一昼夜漫漬し, ゲル化させた，架橋は2.2.1 と同様にし て行った。 反応後沪過し, $2 \mathrm{~mol} \mathrm{dm}^{-3}$ 塩化ナトリウム水溶液

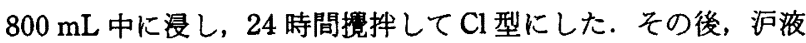
に塩化物イオンが検出されなくなるまで水洗し, 真空乾燥したも のを試料とした.

以上述へたような方法により新しく合成したキトサン誘導体は すべてFT-IRにより同定し，CLC と GCLCについては Schiff 塩基の元素分析から $\mathrm{N} / \mathrm{C}$ 比を求め, それらの置換率を求めた. 第四級化キトサン誘導体である TMC と NTMC の置換率につい ては，これらが Cl 型であるので $1 \mathrm{~mol} \mathrm{dm}^{-3}$ の硝酸ナトリウム 水溶液を用いて $\mathrm{Cl}$ 型を $\mathrm{NO}_{3}$ 型にし，キトサン誘導体から遊離し た塩化物イオン濃度を改良 Volhard 法により定量して ${ }^{13)}$ 各キト サン誘導体の固換率を求めた．その結果 CLC, GCLC については $90 \%$ 以上の置換率が得られ，TMC およびNTMC の眉換率はそ れぞれ60\%および 63\%であった.

硝酸イオン鋳型架橋第四級化キトサン(NTMC)のイオン認識 の概念図を以下の Fig. 1 に示した. 先に示した NTMC の調整法 に従ってキトサン誘導体を合成すると，図に示すような硝酸イオ ン固有の空間である鋳型が形成され，そのためイオンの大きさの 違いによる硝酸イオンの選択的認識が可能であると期待される.

\section{3 吸着実験}
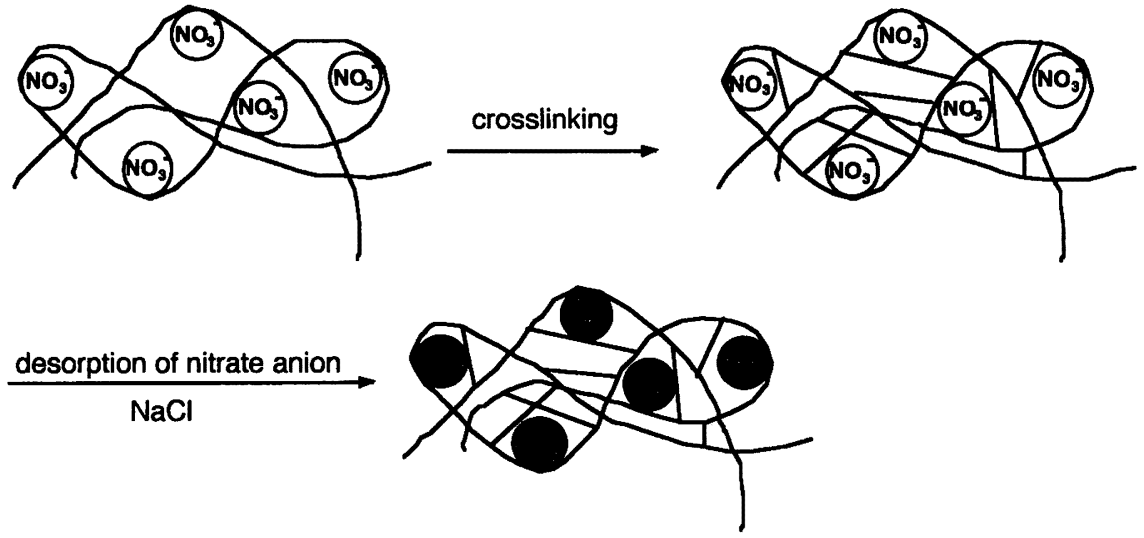

characteristic space of nitrate anion

Fig. 1 Concept of molecular printing of nitrate anion. 
水相として硝酸イオン $100 \mathrm{ppm}$ を含む水溶液を用い, 初期 $\mathrm{pH}$ を1ー12の範囲で調整した。 $\mathrm{pH}$ 調整には, 塩酸と $1 \mathrm{~mol}$ $\mathrm{dm}^{-3}$ 水酸化ナトリウムを用い, $\mathrm{pH}$ を調整した各々の試料溶液 を $15 \mathrm{~mL}$ ずつサンプル瓶に採り，樹脂 $0.05 \mathrm{~g}$ を加え $30^{\circ} \mathrm{C}$ 佰温槽 中で, 24 時間振とうした. 樹脂は, 上述の方法により新しく合 成した 4 種類のキトサン誘導体を使用した．平衡にするために 24 時間振とう後, 溶液を汇過して平衡 $\mathrm{pH}$ を測定した。 また平 衡後の硝酸イオン濃度は, イオンクロマトグラフィー (SHIMADZU PIA-1000)を用いて定量した。

\section{3 結果と考察}

\section{1 キトサン誘導体の合成とその化学構造}

測定されたFT-IR のスペクトルの結果から，本研究で合成さ れたキトサン誘導体は，すへてキトサン糖構造特有の吸収バンド $879 \mathrm{~cm}^{-1}$ と $1157 \mathrm{~cm}^{-1}$ が確認された ${ }^{14)}$. CLC ではキトサン由来 のアミノ基の変角振動の吸収バンドが, $1586 \mathrm{~cm}^{-1}$ に認められ た ${ }^{15)}$. CLC および GCLCは, 中間生成物の Schiff 塩基 $\mathrm{C}=\mathrm{N}$ に 基づく1630-1650 $\mathrm{cm}^{-1}$ 付近の吸収バンドを確認し, 水素化ホ ウ素ナトリウムによる還元によりこの吸収が消隇することが確認 された，TMC およびNTMCでは，アミノ基の吸収バンドが减 少し,メチル基の横ゆれ振動の吸収バンドが, $842 \mathrm{~cm}^{-1}$ に年), また第四級アンモニウム塩のメチル基の変角振動の吸収バンドが, $1420 \mathrm{~cm}^{-1}$ に各々確認された ${ }^{17)}$ 。このようにして得られたキト サン誘導体の構造をFig. 2 に示した．これらのキトサン誘導体 は,すべて酸, アルカリ溶液に安定であった。

3.2 キトサン誘導体による単一溶液からの硝酸性空素の吸着 特性

各キトサン誘導体による硝酸イオン吸着に及ぼす $\mathrm{pH}$ の影響を Fig. 3 に示す. CLC および GCLC は $\mathrm{pH}=3-4$ の領域で最大吸 着量を示し, 中性付近ではほとんど吸着しないことがわかった. 吸着部位にそれぞれ第一級アミンおよび第二級アミンを有する CLC および GCLC は，キトサン自身の酸解離定数 $\left(\mathrm{p} K_{\mathrm{a}}=6.3\right)^{18)}$ を考慮すると, $\mathrm{pH}$ が高くなると水素イオン濃度が低くなってフ ロトン付加されず, そのため $\mathrm{pH}$ の増加に伴って硝酸イオンの吸 着量は減少したと考えられる.一方, $\mathrm{pH}$ が低い領域では $\mathrm{pH} の$ 低下と共に硝酸イオンの吸着量が減少している.これは, $\mathrm{pH}$ 調 整に用いた塩酸から遊離した塩化物イオンが硝酸イオンに比へて 大過剩となり，優先的に塩化物イオンが吸着され，硝酸イオンの 吸着が妨げられたと考えられる.

吸着部位が第四級アンモニウム塩である TMC および NTMC

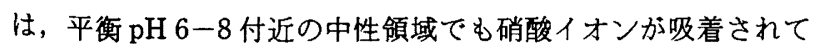
いる. しかし， $\mathrm{pH}$ が高くなると $\mathrm{pH}$ 調整のために用いた水酸化 ナトリウム由来の水酸化物イオンが硝酸イオンに比べ大過剩とな り, 水酸化物イオンが優先的に吸着され, 硝酸イオンの吸着が妨 げられたと考えられる. また，中性付近ではNTMCは，同じ官 能基を有する TMC と比較すると約 2 倍程度の高い吸着量を示 しておりこれは硝酸イオンを鋳型にした鋳型効果が発現したも のと考えられる.

以上の結果から, CLC および GCLCによる硝酸イオンの吸着 平衡を次のように考察した. CLC 抢よびGCLCはほほ同様の $\mathrm{pH}$ 依存性を示し，しかも $\mathrm{pH}=7$ 以下での吸着現象であるので， ここでは吸着反応式を式 (1)で示される中和反応と考えた。ま

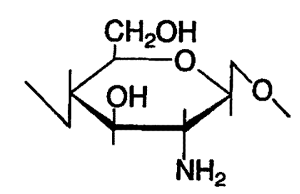

Chitosan

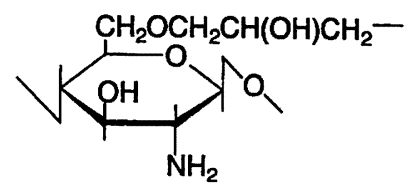

CLC

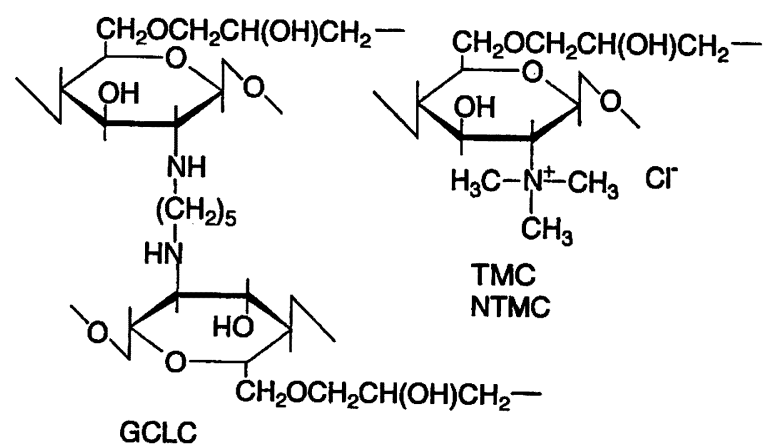

Fig. 2 Structure of chitosan derivatives.

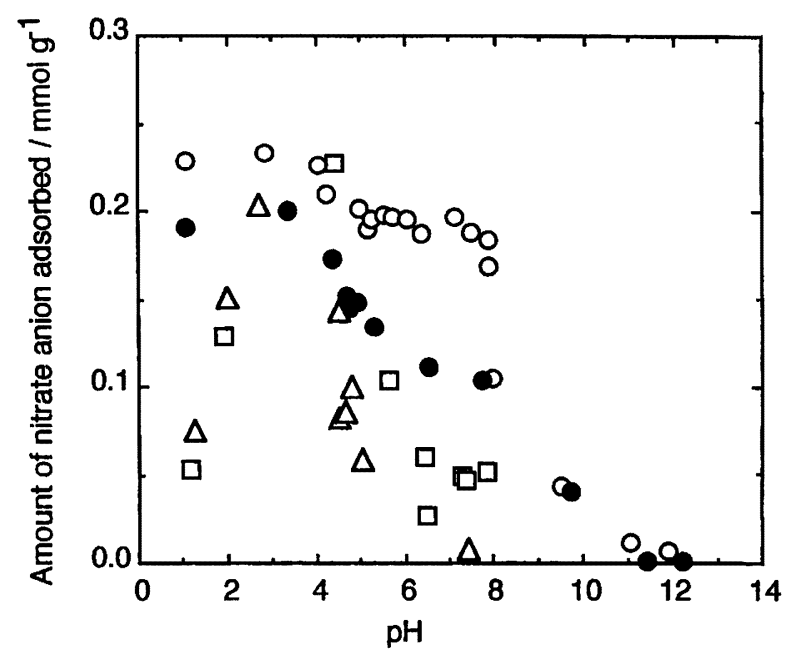

Fig. 3 Effect of $\mathrm{pH}$ on adsorption of nitrate anion with chitosan derivatives.

O: NTMC, : TMC, $\square$ : GCLC, $\triangle$ : CLC.

た, $\mathrm{pH}$ の低い領域では $\mathrm{pH}$ 調整のために用いた塩酸からの塩化 物イオンとの競争反応が考えられ，それは(2)式で示される.

$$
\begin{aligned}
& \overline{\mathrm{RN}}+\mathrm{H}^{+}+\mathrm{NO}_{3}{ }^{-}=\overline{\mathrm{RNHNO}_{3}} ; K_{1} \\
& \overline{\mathrm{RN}}+\mathrm{H}^{+}+\mathrm{Cl}^{-}=\overline{\mathrm{RNHCl}} ; K_{2}
\end{aligned}
$$

吸着剤の物質収支は以下のように考えられる.

$[\overline{\mathrm{RN}}]_{0}=[\overline{\mathrm{RN}}]+\left[\overline{\mathrm{RNHNO}_{3}}\right]+[\overline{\mathrm{RNHCl}}]$

本実験条件下では

$$
\approx[\overline{\mathrm{RN}}]+[\overline{\mathrm{RNHCl}}]
$$

と近似される.

さらに，電荷の中性条件より次式が得られる.

$\left[\mathrm{H}^{+}\right] \approx\left[\mathrm{Cl}^{-}\right]$

これらの式 $(1)$ - ( 5 ) から, 分配比 $D$ は次のように表すこと ができる. 


$$
D=\frac{K_{1}\left[\mathrm{H}^{+}\right][\overline{\mathrm{RN}}]_{0}}{1+K_{2}\left[\mathrm{H}^{+}\right]^{2}}
$$

高 $\mathrm{pH}$ 領域では (6) 式は (7) 式のように近似され，その対数 をとると(8)式が得られる.

$$
\begin{aligned}
& D=K_{1}\left[\mathrm{H}^{+}\right][\overline{\mathrm{RN}}]_{0} \\
& \log D=-\mathrm{pH}+\log K_{1}{ }^{\prime} \quad\left(K_{1}{ }^{\prime}=K_{1}[\overline{\mathrm{RN}}]_{0}\right)
\end{aligned}
$$

(8) 式は $\log D$ と $\mathrm{pH}$ をプロットすると傾きー1の直線が得ら れ，その切片から $K_{1}^{\prime}$ が得られることを示している.

一方，低 $\mathrm{pH}$ 領域では式 (6)は式 (9)のように近似され，そ の対数をとると式(10)が得られる.

$$
\begin{aligned}
& D=\frac{K_{1}}{K_{2}\left[\mathrm{H}^{+}\right]}[\overline{\mathrm{RN}}]_{0} \\
& \log D=\mathrm{pH}+\log \left(K_{1}^{\prime} / K_{2}\right) \quad\left(K_{1}^{\prime}=K_{1}[\overline{\mathrm{RN}}]_{0}\right)
\end{aligned}
$$

(10)式は $\log D$ と $\mathrm{pH}$ をプロットすると傾き 1 の直線が得られ， その切片から $K_{1}^{\prime} / K_{2}$ が得られることを示している.これらの式 （8）および(10)は，Fig. 3 で示した各 $\mathrm{pH}$ 領域における硝酸イオ ンの吸着結果を合理的に説明できた。 これらの式に基ういて解析 を行い, 各 $\mathrm{pH}$ 領域から得られた切片の值から, みかけの吸 着平衡定数 $K_{1}{ }^{\prime}=1.51 \times 10^{8}\left(\mathrm{dm}^{3}\right)^{2}(\mathrm{~mol} \mathrm{~g})^{-1}$ 扰よび $K_{2}=1.95$ $\left(\mathrm{dm}^{3} \mathrm{~mol}^{-1}\right)^{2}$ が得られた. これらの吸着平衡定数を用いて, 式 （6）に基うく計算線をFig. 4 の実線で示す. 計算線は実験值と ほほ一致しており，硝酸イオンの吸着のほとんどは，式(1)，(2) に示す中和反応によって起こると考えられる.

一方，第四級アンモニウム塩を有するキトサン誘導体，TMC およびNTMC による硝酸イオンの吸着は次のように考えられ る.すなわち、これらのキトサン誘導体の吸着は式(11)に基う いた硝酸イオンと塩化物イオンのイオン交換で起こると考えた.

$$
\overline{\mathrm{RN}^{+} \mathrm{Cl}^{-}}+\mathrm{NO}_{3}{ }^{-}=\overline{\mathrm{RN}^{+} \mathrm{NO}_{3}{ }^{-}}+\mathrm{Cl}^{-} ; K_{3}
$$

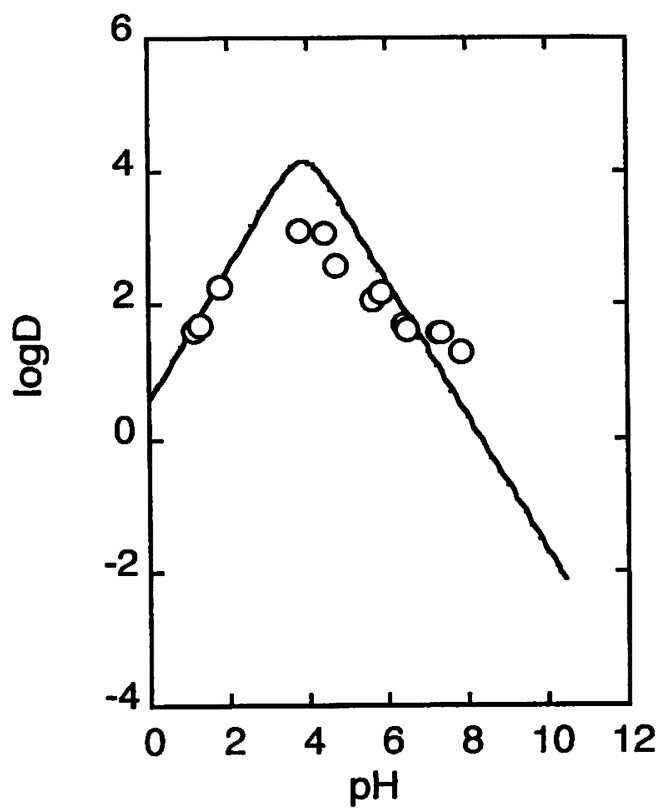

Fig. 4 Effect of $\mathrm{pH}$ on the distribution ratio of nitrate anion with GCLC.

- Calculated curve.
さらに $\mathrm{pH}$ の高い領域では，以下に示す式(12)のイオン交換反応 が起こり，硝酸イオンの吸着は减少していると考えた。

$$
\overline{\mathrm{RN}^{+} \mathrm{Cl}^{-}}+\mathrm{OH}^{-}=\overline{\mathrm{RN}^{+} \mathrm{OH}^{-}}+\mathrm{Cl}^{-} ; K_{4}
$$

吸着剤の物質収支は，本実験条件下では次のように考えられ る。

$$
\begin{aligned}
{\left[\overline{\mathrm{RN}^{+} \mathrm{Cl}^{-}}\right]_{0} } & =\left[\overline{\mathrm{RN}^{+} \mathrm{NO}_{3}}-\right]+\left[\overline{\mathrm{RN}^{+} \mathrm{Cl}^{-}}\right]+\left[\overline{\mathrm{RN}^{+} \mathrm{OH}^{-}}\right] \\
& \approx\left[\overline{\mathrm{RN}^{+} \mathrm{Cl}^{-}}\right]+\left[\overline{\mathrm{RN}^{+} \mathrm{OH}^{-}}\right]
\end{aligned}
$$

以上の式(11)-(13)を考虑すると分配比 D は次のように表さ れる.

$$
D=\frac{K_{3}\left[\mathrm{H}^{+}\right]\left[\overline{\mathrm{RN}^{+} \mathrm{Cl}^{-}}\right]_{0}}{K_{4} K_{\mathrm{w}}+\left[\mathrm{H}^{+}\right]\left[\mathrm{Cl}^{-}\right]}
$$

（14）式は各 $\mathrm{pH}$ の領域で次のように近似される。

まず，低 $\mathrm{pH}$ 領域では

$$
\begin{gathered}
D=K_{3}\left[\overline{\mathrm{RN}^{+} \mathrm{Cl}^{-}}\right]_{0} /\left[\mathrm{Cl}^{-}\right]=K_{3}^{\prime} /\left[\mathrm{Cl}^{-}\right] \\
\quad\left(K_{3}^{\prime}=K_{3}\left[\overline{\mathrm{RN}^{+} \mathrm{Cl}^{-}}\right]_{0}\right)
\end{gathered}
$$

この領域では(11)式の反応が起こっており，この領域で測定さ れた塩化物イオンの瀆度はほほ一定であったので，低 $\mathrm{pH}$ 領域で の分配比は一定であると考えられる.

一方，高 $\mathrm{pH}$ 領域では

$$
D=\frac{K_{3}\left[\mathrm{H}^{+}\right]\left[\overline{\mathrm{RN}^{+} \mathrm{Cl}^{-}}\right]_{0}}{K_{4} K_{\mathrm{w}}}
$$

となり，両边の対数をとると

$$
\log D=-\mathrm{pH}+\log \left(K_{3}{ }^{\prime} / K_{4}{ }^{\prime}\right) \quad\left(K_{4}^{\prime}=K_{4} K_{\mathrm{w}}\right)
$$

これらの式は，TMCおよびNTMCによる硝酸イオンの吸着現 象をほほ説明している. 式(15), (17) 上り求めた吸着平衡定数 $K_{3}^{\prime}$ および $K_{4}^{\prime}$ の值は， $K_{3}{ }^{\prime}=9.55 \times 10 \mathrm{~mol} \mathrm{~g}^{-1}, K_{4}{ }^{\prime}=3.02 \times 10^{6}$ $\left(\mathrm{mol} \mathrm{dm}^{-3}\right)^{2}$ であった．これらの值を用いて式(14)に基ついた 計算線を Fig. 5 に示す. 実験值とほほ一致していることから， 硝酸イオンの吸着は式(11)，(12)に示した陰イオン交換反応によ

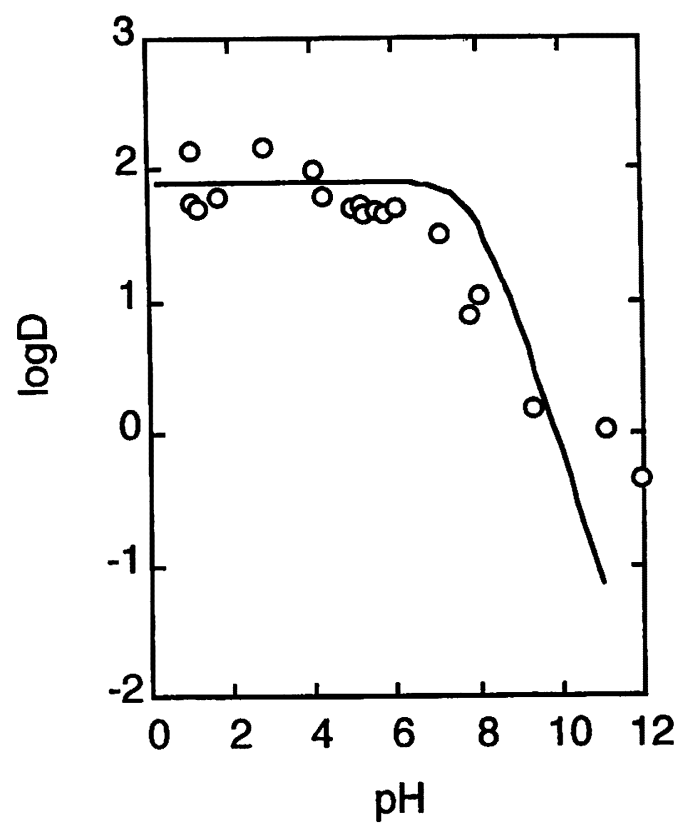

Fig. 5 Effect of $\mathrm{pH}$ on the distribution ratio of nitrate anion with NTMC.

_- Calculated curve. 
って起こると考えられる.

3.3 各種キトサン誘導体による㓌イオン混合水溶液中からの 硙酸イオン吸着特性

Fig. 6 は, 各キトサン誘道体による塩化物イオン, 硫酸イオン および硝酸イオンの混合溶液からの吸着平衡を調へた結果を相対 的に示したものである. 领料水の $\mathrm{pH}$ 領域である $\mathrm{pH}=6.5-6.7$ で実験を行ったため，第四級アンモニウム塩を有する TMC およ びNTMC が高い吸着量を示しているが, 単一溶液からの吸着で 鋳型効果が発現したNTMC の硝酸イオンに対する選択性が明確 に現れていない，これは混合溶液からの吸着では，硫酸イオンが 二価の陰イオンであるため, 一価の陰イオンである硝酸イオンよ りむ強い静電的相互作用を示すためと考えられる. また，イオン 交換により吸着された陰イオンの総量と，それに伴って溶離して きた塩化物イオンの量とを比較すると化学量論関係が成立してい ないことがわかる.これについては現在のところ明確な解答は得 られておらず，第四級化されずに残っているキトサン由来のアミ ンによる硫酸イオンの吸着など,ささらに詳細に検討する必要があ る. また，総イオン量に対する硝酸イオンの選択性は，官能基と して第一級アミンを有するCLCよりむ官能基として第二級アミ ンを有する GCLC が最む優れており，硝酸イオンに対する選択 性は $\mathrm{pH}=6.5-6.7$ の領域においては第一級アミンより第二級ア ミンの方が優れていることがわかった。しかし，この pH 領域で は吸着量が小さく，吸着量についてはさらに検討する必要があ る.

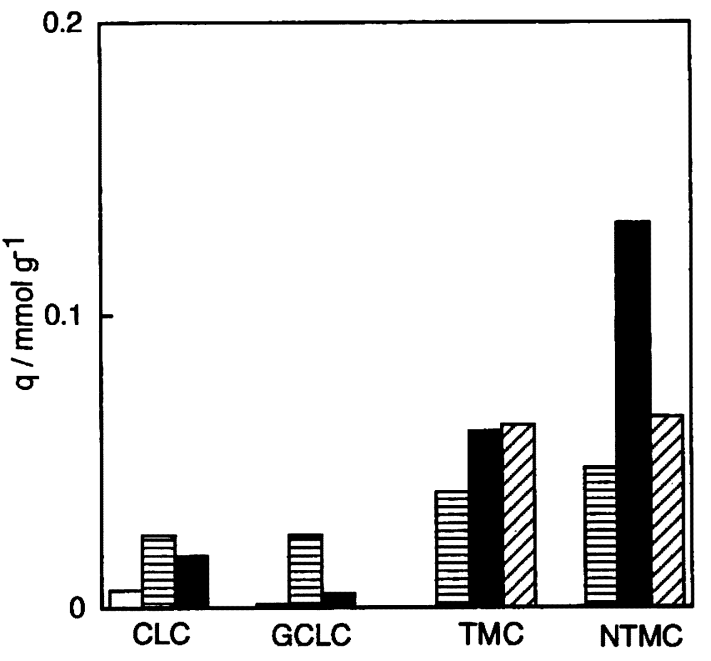

Fig. 6 Comparison of adsorption of nitrate anion on chitosan derivatives.

$\square$ : Chloride anion, 目: nitrate anion, $\square$ : sulfate anion, $\square$ : desorbed chloride anion.

\section{4 結論}

本研究では, 各種の官能基を有するキトサン誘導体の合成を行 い，硝酸イオンに対する吸着特性を検討した。これらの結果か ら，遊離のアミンを有するキトサン誘導体による硝酸イオンの選 択性は, $\mathrm{pH}=6.5-6.7$ の領域では第一級アミンを有する CLC よ りむ第二級アミンを有する GCLC の方が高い選択性を示した. しかしながら,これらの吸着は中和反応による吸着であるために 中性付近での吸着量は急激に減少した。一方，第四級アンモニウ ム型の TMC およびNTMC は中性付近でも高い吸着性を示し た. 特に, 硝酸イオンの単一溶液系からの吸着では, 硝酸イオン の鋳型構造を有すると考えられるNTMCによる吸着量が，鋳型 構造を有していないTMCの 2 倍の吸着量を示したが, 混合水 溶液からの吸着では, 二価の硫酸イオンの強い静電相互作用によ り一価の硝酸イオンに対する選択性の低下を引き起こした．この ように, キトサン上に設計された鋳型構造は，キトサンが膨潤す ることによって強固な鋳型構造を保つことができず，鋳型効果は 徽妙なバランスのもとで発現しており, 単一試料のように他に競 争するむのがない場合にのみ発現するむのと推測される.

1）この報文を“高選択性吸着樹脂に関する研究（第 4 報）” とする.

2）前報（第 3 報），Y. Baba， N. Matsumura，K. Shiomori， Y. Kawano, Anal. Sci., 14, 687(1998).

3) J. Power, F. Schepers, J. S. Agric. Ecosys. Environ., 26, 165(1989).

4) H. Vierchuff, Wat. Qual., Bull., 14, 152(1989).

5）杉戸大作，水道協会雑誌，52(10), 53(1983).

6） キチン, キトサン研究会編, “キチン, キトサンの応用”, 技報堂出版 (1990).

7) K. Inoue, Y. Baba, K. Yoshizuka, Bull. Chem. Soc. Jpn., 66, 2915(1993).

8) Y. Baba, K. Masaaki, Y. Kawano, Chem. Lett., 1994, 2389.

9) Y. Baba, Y. Kawano, H. Hirakawa, Bull. Chem. Soc. Jpn., 69, 1255(1996).

10) Y. Baba, K. Masaaki, Y. Kawano, React. Func. Polym., 36, 167(1998).

11) K. Ohga, Y. Kurauchi, H. Yanase, Bull. Chem. Soc. Jpn., 60, 444(1987).

12）キチン, キトサン研究会編, “キチン, キトサン実験マニ エアル”, 技報堂出版 (1992).

13）大橋弘三郎, 小熊幸一, 鎌田薩男, 木原壮林, “分析化 学”, 三共出版社 (1992), pp. 132, 133.

14）見矢 勝, 岩本令吉, 大田浩二, 美馬精一, 高分子論文 集, 42, 181(1985).

15）片岡清一, 高分子論文集, 39, 759(1982).

16）島内武彦, “赤外吸収スペクトル解析法”, 南江堂(1974), p. 68.

17) E. Loubaki, M. Ourevitch, S. Sicsic, Eur. Polym. J., 27, 311(1991).

18) R. A. A. Muzzarelli, "Chitin”, Pergamon, Oxford (1976). 


\section{Synthesis of Chitosan Derivatives and Their Adsorption Properties for Nitrate Anion ${ }^{\dagger}$

\author{
Yoshinari BABA*, Kohji OHGUMA ${ }^{\text {Ht }}$ and Yoshinobu KAwANO \\ Department of Material Science, Faculty of Engineering, Miyazaki University; \\ Gakuen-kibanadai Nishi 1-1, Miyazaki-shi 889-2192 Japan \\ "Chisso Ltd., Co.; Noguchi-machi, Minamata-shi 867-0053 Japan
}

In order to develop an effective adsorbent for nitrate anion from ground water, four kinds of chitosan derivatives containing the primary amine $(C L C)$, the secondary amine $(G C L C)$, the quaternary ammonium (TMC) and the quaternary ammonium (NTMC) imprinted for nitrate anion were synthesized. These adsorption properties for various anions such as nitrate anion, chloride anion, and sulfate anion were examined by a batchwise method at $303 \mathrm{~K}$. The $\mathrm{pH}$ dependencies on the adsorption properties were tested in the adsorption from a single solution containing only nitrate anions. CLC and GCLC exhibited a maximum adsorption of nitrate anions in the $\mathrm{pH}$ region of $3-4$, while these hardly adsorbed it in the region of $\mathrm{pH}$ around 7. On the other hand, the quaternized chitosan derivatives exhibited a high adsorption for nitrate anions even at $\mathrm{pH} 7$, especially, NTMC indicated two times adsorption compared with TMC, owing to a molecularly imprinting effect. This effect has appeared in the adsorption from a solution containing a single solute, while the effect hardly appeared in the adsorption from the mixture solution containing nitrate anion, chloride anion and sulfate anion.

\footnotetext{
${ }^{\dagger}$ Highly Selective Adsorption Resins. Part 4.
} 